\title{
Erratum to: Financial Inclusion and Poverty Alleviation
}

\section{Muhamed Zulkhibri and Abdul Ghafar Ismail}

\section{Erratum to:}

\section{Zulkhibri and A. G. Ismail (eds.), Financial Inclusion and Poverty Alleviation, Palgrave Studies in Islamic Banking, Finance, and Economics, https://doi.org/10.1007/978-3-319-69799-4}

In the original version of the book, in Preface, Page ix, the sentence "Chapter 6 by Muhammad Ayub and Abu Umar Faruq investigates how the Takaful system can be translated as shared responsibility and cooperative risk and reward sharing vehicle." has to be changed as "Chapter 6 by Mohammed Obaidullah and Turkhan Ali Abdul Manap provides a fundamental understanding of behavioral dimensions of Islamic philanthropy in the case of Zakat." The erratum book has been updated with the change.

\footnotetext{
The updated online version for this book can be found at https://doi.org/10.1007/978-3-319-69799-4 